\title{
Making inroads into improving treatment of bacterial vaginosis - striving for long-term cure CrossMark
}

\author{
Catriona S. Bradshaw ${ }^{1,2^{*}}$ and Rebecca M. Brotman ${ }^{3}$
}

\begin{abstract}
Bacterial vaginosis (BV) is one of the great enigmas in women's health, a common condition of unknown aetiology, which is associated with significant morbidity and unacceptably high recurrence rates. While it remains unclear whether $\mathrm{BV}$ recurrence is predominantly due to failure of current antibiotic regimens to eradicate BV-associated bacteria (BVAB) and biofilm, a failure of some women to re-establish a resilient Lactobacillus-dominant vaginal microbiota, reinfection from sexual partners, or a combination of these factors, it is inherently challenging to make significant inroads towards this goal. In this review, we will outline why BV is such a clinical and epidemiologic conundrum, and focus on several key approaches that we believe merit discussion and clinical research, including strategies to: i) prevent reinfection (partner treatment trials), ii) boost favourable vaginal Lactobacillus species and promote a Lactobacillus-dominant vaginal microbiome (hormonal contraceptive and probiotic trials) and iii) disrupt vaginal BV-associated biofilm.
\end{abstract}

Keywords: Bacterial vaginosis, Treatment approaches

\section{Introduction}

Bacterial vaginosis (BV) is one of the great enigmas in women's health, a common condition of unknown aetiology, which is associated with significant morbidity and unacceptably high recurrence rates. In this review, we will outline why BV is such a clinical and epidemiologic conundrum, and propose key research priorities that focus on the common goal, the elusive sustained cure.

\section{Background}

$\mathrm{BV}$ is the most common vaginal infection in women of reproductive age. Prevalence estimates range from $12 \%$ in Australian women [1], to $29 \%$ in North-American women [2,3], and greater than $50 \%$ in women in East/Southern Africa [4]. BV has been associated with serious and costly reproductive and obstetric sequelae, increasing women's risk of pre-term delivery, low birth weight, miscarriage and pelvic inflammatory disease [5]. These sequelae have considerable implications for healthcare expenditure, with the population attributable risk of BV for pre-term delivery in the US estimated

\footnotetext{
* Correspondence: cbradshaw@mshc.org.au

${ }^{1}$ Melbourne Sexual Health Centre, 580 Swanston Street, Carlton, VIC 3053, Australia

${ }^{2}$ Central Clinical School, Monash University, Melbourne, VIC, Australia Full list of author information is available at the end of the article
}

over a decade ago to be $30 \%$, at a cost of USD 1 billion per annum [5].

Longitudinal studies have demonstrated that BV is associated with an approximate 2 -fold increased risk of acquiring sexually transmitted infections including chlamydia, gonorrhoea, herpes simplex type 2 and HIV infection [6-11], and increases the risk of co-infected women transmitting HIV to their male partners [12]. Although significant proportions of women with BV appear to be asymptomatic, over $50 \%$ experience an unpleasant vaginal malodour and discharge, with qualitative studies showing BV is associated with moderatesevere impact on self-esteem, sexual relationships and quality of life in women who have sex with men (WSM) and women who have sex with women (WSW) [13].

While the aetiology and pathogenesis of BV is not completely understood, BV is characterised by depletion of key Lactobacillus spp., high bacterial species diversity and increased loads of facultative anaerobes such as Gardnerella vaginalis, Atopobium vaginae and other fastidious BVassociated bacteria (BVAB) including Megasphaera, Sneathia and Clostridiales spp. compared to healthy controls [14-16]. Most vaginal Lactobacillus spp. provide broad-spectrum protection against pathogens through production of potent antimicrobial molecules, bacteriocins and lactic acid [17-19], with the latter acting as a broad- 
spectrum bactericide and virucide, and maintaining vaginal pH between 3.5 and 4 [20,21]. Lactic acid appears to possess antimicrobial activity beyond acidity alone, by disrupting the integrity of bacterial cell membranes and stimulating innate immunity in the presence of bacterial lipopolysaccharide [20-22]. Recent work has also demonstrated that lactobacilli can interfere with the ability of pathogens such Trichomonas vaginalis to adhere to host cells [23]. Overall there is a significant body of evidence indicating most Lactobacillus-dominant vaginal microbiomes, with the exception of L. iners [24-29], are optimal for maintaining vaginal and reproductive health.

Recent work has identified a vaginal wall biofilm in women with BV, dominated by G.vaginalis and A.vaginae, that is absent in healthy controls $[30,31]$. While it is thought this biofilm may contribute to the low success rate of current antibiotic therapies, the role of the biofilm in BV pathogenesis is not clear as in vivo vaginal epithelial cells are shed rapidly throughout the menstrual cycle [32]. BV research is further impeded by the fact that primate and other animal models are not optimal for the study of the cervico-vaginal microbiota because the vaginal $\mathrm{pH}$ is higher $(>5)$ and the resident microbiota differ from that of humans [33-37]. There are, for example, high proportions of streptococci in mice [35] and Corynebacterium in the guinea pig [34]. Humans also have significantly lower bacterial richness and diversity estimates compared to nonhuman primates, and the relative abundances of lactobacilli are significantly lower in non-human primates [33].

While short term BV cure rates following first line recommended therapies (5-7 days of metronidazole or clindamycin) approach $80 \%$ [38], failure rates in excess of $50 \%$ occur within 6-12 months [39, 40]. Higher baseline loads of several BVAB have been associated with increased risk of recurrence [41], and some data suggest BV-associated biofilm rapidly re-accumulates following antibiotics [31]. However, strategies such as suppressive antibiotic regimens that attempt to eradicate persistence of BVAB, have not achieved sustained high long term cure $[42,43]$.

While it remains unclear whether BV recurrence is predominantly due to failure of current antibiotic regimens to eradicate BVAB and biofilm, a failure of some women to re-establish a resilient Lactobacillus-dominant vaginal microbiota, reinfection from sexual partners, or a combination of these factors, it is inherently challenging to make significant inroads towards this goal, Fig. 1. We will focus this review on several key approaches that we believe merit discussion and clinical research, including strategies to: i) prevent reinfection (partner treatment trials), ii) boost favourable vaginal Lactobacillus species and promote a Lactobacillus-dominant vaginal microbiome (hormonal contraceptive and probiotic trials) and iii) disrupt vaginal $\mathrm{BV}$-associated biofilm.

\section{Strategies to address potential reinfection (partner treatment trials)}

BV has been strongly associated with sexual activity in epidemiological studies. Women with BV have an earlier median age of sexual debut than women without BV [44], and BV has been associated with increased numbers of recent and lifetime sexual partners and inconsistent condom

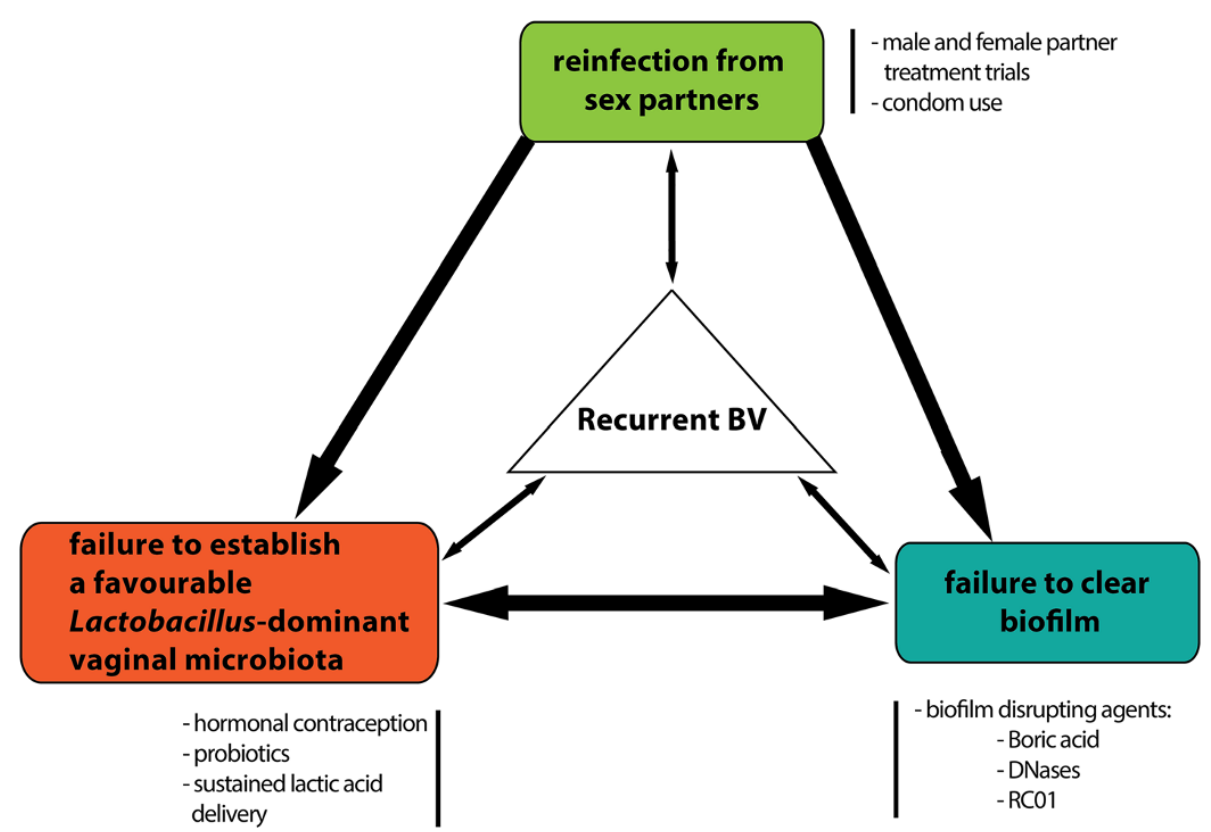

Fig. $1 \mathrm{BV}$ recurrence and potential therapeutic strategies 
use by meta-analysis [45]. A study of young female university students found BV to be absent in women with no history of sexual activity, to be uncommon in women who had engaged only in non-coital sexual activities and to be significantly associated with penile-vaginal sex [46]. Prior studies identifying BV in "virgins" had limited questioning to history of penile-vaginal sex $[47,48]$. The concept that BV may be sexually transmitted has been controversial for many years due to difficulties encountered in determining its aetiology, absence of corresponding disease in males, and failure of male partner treatment trials to reduce recurrence $[49,50]$. A recent systematic review by Mehta concluded that insufficient power, use of non-standard treatment regimens, no measures of adherence, and poor retention, rendered the findings of past partner treatment trials inconclusive by current standards, and recommended larger trials using recommended therapies be conducted [50]. Further support for sexual transmission of BV includes published data which indicates that the poor long-term performance of recommended therapies may at least partly be attributed to post-treatment sexual behaviours. Women exposed to an ongoing partner pre- and post-treatment were at a 2-3 fold increased risk of BV recurrence after adjusting for sexual frequency, condom use and hormonal contraception in two studies [40,51], and several, but not all studies, found inconsistent condom use and unprotected penile-vaginal sex to be associated with recurrence [51-53]. Male carriage of G.vaginalis, an organism implicated in the development of BV [54], is commonly reported [55-57]. Pyrosequencing of the microbiota of the coronal sulcus and distal-urethra in young males has also showed these sites to be colonised by BVAB, and the composition of the sulcus microbiota to be influenced by circumcision and sexual activity [58]. Male circumcision was not only associated prospectively with a significant reduction in penile anaerobes, including $\mathrm{BV}$-associated genera [59], but a secondary analysis within a male circumcision trial showed wives of circumcised males had a reduced risk of $\mathrm{BV}$ (adjPRR $=0.60 ; 95 \% \mathrm{CI}=0.38-0.94$ ) compared to wives of controls [60]. While there are few studies examining BV-associated biofilm in men, biofilm has been detected in male urine and semen, and more commonly found in the male partners of females with BV than healthy controls [61]. Overall this body of evidence provides increasing support for the hypothesis that BV is sexually transmitted between men and women.

International BV research has had a strong focus on women who predominantly have sex with men. However, WSW also experience BV and are in need of relevant clinical and epidemiological research. A number of studies have confirmed BV to be prevalent in WSW with estimates ranging from 25 to $52 \%$ [62-66]. Female same-sex partnerships provide an important model to understand the pathogenesis and transmissibility of BV, as unlike in male-female partnerships, BV can be diagnosed in both partners. BV has been strongly associated with sexual risk factors in WSW including: increased number of female partners, a female partner with BV and receptive oral sex [63, 65-68]. Female couples in monogamous relationships have high concordance of Nugent category $[62,63,65,66,68]$, and share Lactobacillus strain types [69]. In a recent communitybased cohort study of 298 WSW, incident BV was significantly associated with exposure to a new female sexual partner and a female partner with BV symptoms [68]. In contrast, co-enrolled couples who were BV-negative at enrolment had a very low risk of incident BV over two years, and their vaginal microbiota remained aligned, stable and within the "normal" Nugent category. This study provides compelling evidence for dynamic exchange of vaginal bacterial species between female partners, and extends our understanding of the influence of sexual behaviours and relationships on the vaginal microbiota and risk of BV.

Collectively, published clinical and epidemiological data suggests sexual transmission of BV is at least likely to be contributing to the development of $\mathrm{BV}$ and to post-treatment recurrence. These data provide broad support for the need to repeat and fund sufficiently powered male and female partner treatment trials to determine if this strategy reduces BV recurrence and associated sequelae. There is currently one registered male partner treatment trial enrolling couples in North America in which men are randomized to oral metronidazole versus oral placebo and these data are eagerly awaited (ClinicalTrials.gov Identifier: NCT02209519). Trials involving the use of topical in addition to oral agents are planned, and may be necessary to eradicate cutaneous carriage of BVAB from the penile skin. Female partner treatment trials, while clearly needed, are logistically more challenging as randomization of symptomatic female partners to treatment or placebo may not be acceptable or ethical; the design of such studies will clearly need careful thought and innovation.

\section{Strategies to boost favourable Lactobacillus spp.: vaginal probiotics and hormonal contraceptives}

Surveys of the vaginal microbiota have found there are fundamental differences in the microbial diversity of vaginal communities present in reproductive age women [70-76]. In one U.S. study of 394 women, Ravel et al. characterized the vaginal microbiota using $16 \mathrm{~S}$ rRNA gene analysis amplified from whole genomic DNA isolated from vaginal swabs [70], Fig. 2. Five vaginal microbiota groupings, termed community state types (CSTs), were identified. Four CSTs were dominated by one of four Lactobacillus species, while the fifth was depleted of Lactobacillus. The latter CST contained high proportions of anaerobic bacteria, resembling BV. The frequencies of each CST varied 


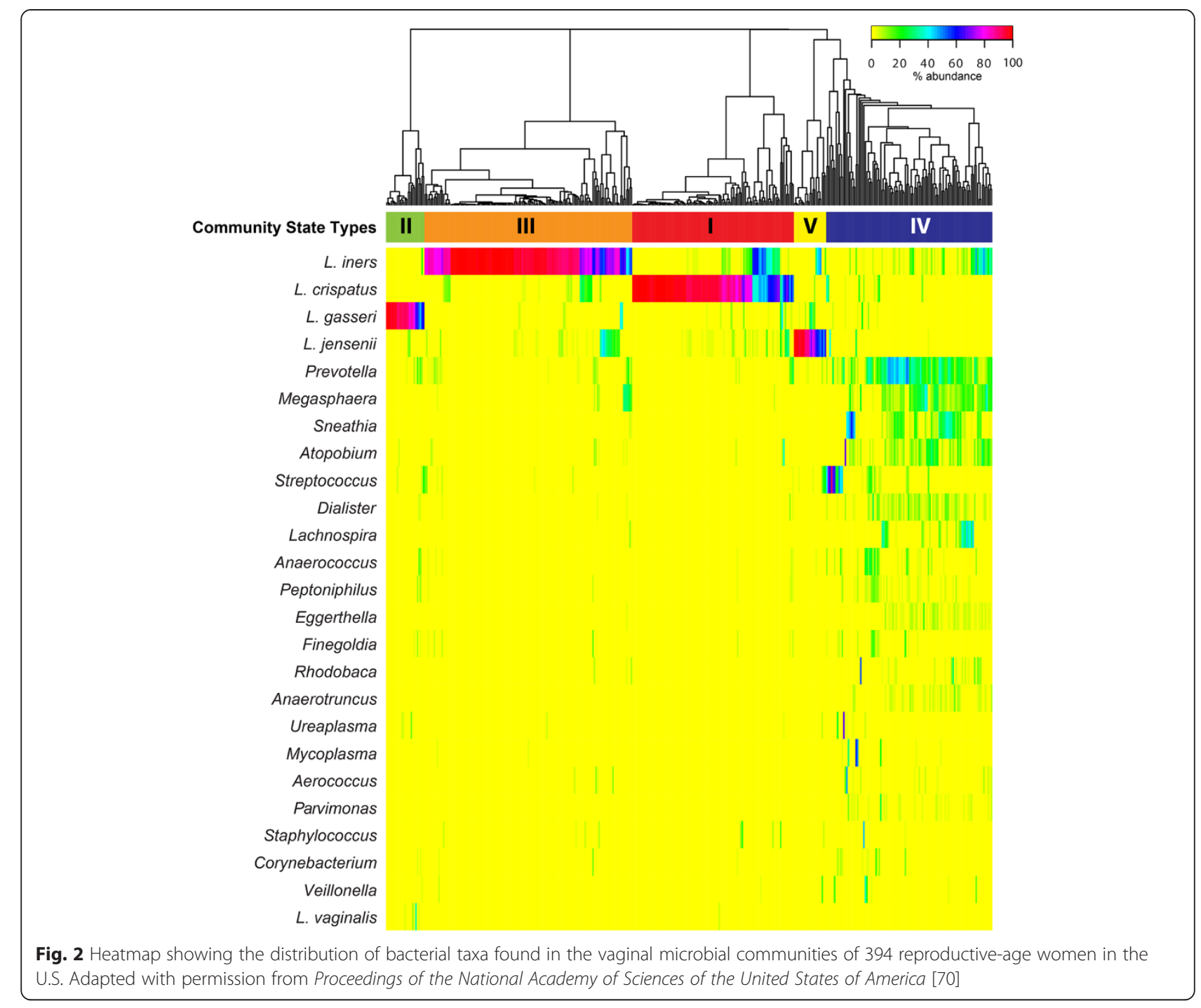

by ethnicity, and African American and Hispanic women were more likely to be Lactobacillus-depleted. Longitudinal studies have also demonstrated that some women experience frequent and rapid fluctuations in the composition of the vaginal microbiota, while in others, the microbiota are remarkably stable [77-79], Fig. 3. These surveys are particularly relevant to the development of probiotics, which aim to reseed dysbiotic microbiomes.

Probiotics that have been evaluated in studies have contained a range of Lactobacillus spp. (L. acidophilus, L. gasseri. L. fermentum. L. rhamnosus and L. crispatus), not all of which are endogenous to the vagina. In 2009, a Cochrane review found no conclusive evidence to recommend for or against probiotic use for the treatment of BV [80]. However, a recent body of research has begun to rigorously evaluate the efficacy of intravaginal and oral probiotic formulations to treat $\mathrm{BV}$ and to restore a Lactobacillus-dominant microbiota [80-83]. In a study of 90 women without BV who used the intravaginal delivery of L. crispatus CTV-05, Antonio et al. reported good CTV-05 colonization rates (59\%) at 28 days [83]. Subsequently, Ngugi et al. reported on the use of CTV-05 in 24 women with BV [84] and reported $44 \%$ of BV cases were colonized with CTV-05 at 28 days, and cases not colonized had higher median concentrations of BV-associated bacteria. Those who were colonized had significant reductions in Atopobium vaginae, a bacterium associated with BV. Importantly, vaginal intercourse was found to significantly impair CTV-05 colonization in both studies, and endogenous $L$. crispatus also reduced the CTV-05 colonization rate [83, 84]. Clinical trials to assess the efficacy of CTV-05 for BV are in progress. A study of another intravaginal probiotic (containing L. brevis, L. salivarius subsp. salicinius, and L. plantarum) found $61 \%$ did not have BV by Amsel and Nugents criteria at 2 weeks compared to $19 \%$ in the placebo group [85]. Using two wellcharacterized strains (Lactobacillus rhamnosus GR-1 


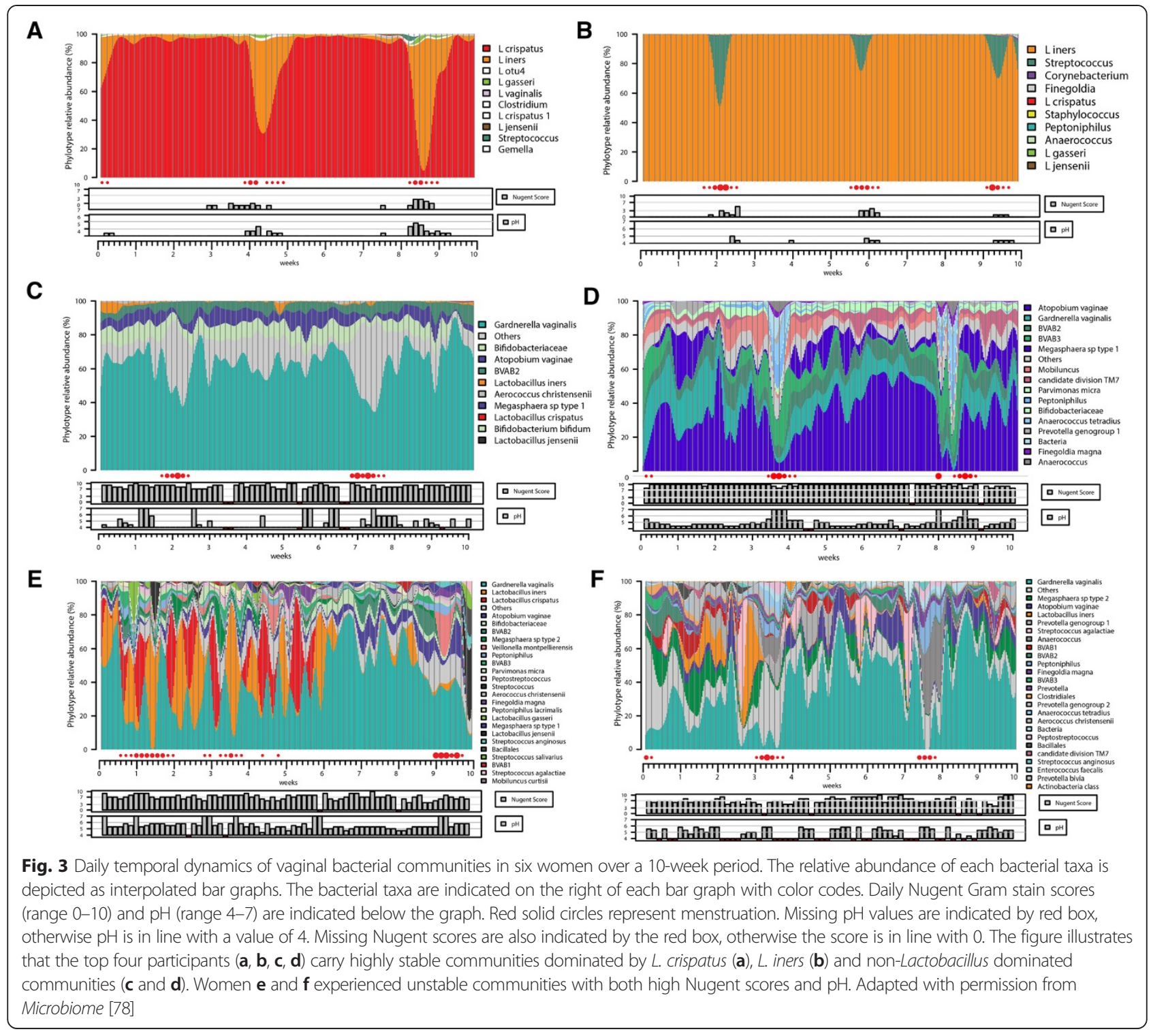

and Lactobacillus fermentum RC-14), delivered by oral capsules, Reid et al. [86] reported a significant increase in vaginal lactobacilli on Gram stain and culture at day 28 and 60 in a randomized, placebocontrolled trial of 64 healthy women. Martinez et al. combined antibiotics and probiotics in a study of 32 women randomized to oral capsules of Lactobacillus rhamnosus GR-1 and Lactobacillus reuteri RC-14 following $2 \mathrm{~g}$ of tinidazole, and reported a BV cure rate at four weeks of $87 \%$ in the Lactobacillus group compared to $50 \%$ in the tinidazole-only group [87].

Although recent results are encouraging, these are relatively small studies with varying exclusion criteria and short follow-up. The overall conclusions of the recent Cochrane review and the latest U.S. CDC treatment guidelines are that current evidence does not yet support the addition of any available Lactobacillus formulations or probiotics as an adjunctive or replacement therapy in women with BV [80, 88]. There clearly remains a need for larger, well-designed, double-blind, placebocontrolled trials of various probiotic formulations, in combination with, or in comparison to, standard treatments. Probiotic trials need to standardize their methods for evaluating BV and given the high recurrence rates reported in trials that extend follow up to 6-12 months $[40,42]$, studies with more prolonged of observation post-treatment are important. As some evidence suggests a woman's endogenous microbiota may impact on probiotic success rates, it is likely that future therapeutic approaches will need 
to include personalized probiotic or prebiotic recommendations based on a woman's individualized temporal CST pattern.

Another adjunctive approach that is being investigated to try and reduce BV following antibiotic therapy is hormonal contraception (HC). Epidemiological data, including a meta- analysis, suggest that oral contraceptive pills (OCP) are associated with a decreased risk of prevalent and incident BV, Figs. 4 and 5 [51, 89-93]. This meta- analysis also suggested that progestin-only oral contraceptives (POC) reduce BV to a similar magnitude seen with combined hormonal contraceptives [93]. Data on the influence of contraceptive vaginal rings on the local microenvironment are still sparse [94, 95], and there is inconsistent evidence on how copper and hormonal intrauterine devices (IUD) affect the vaginal microbiome [90, 96-98]. Overall, where data on $\mathrm{HC}$ are conflicting, it is most likely due to a number of

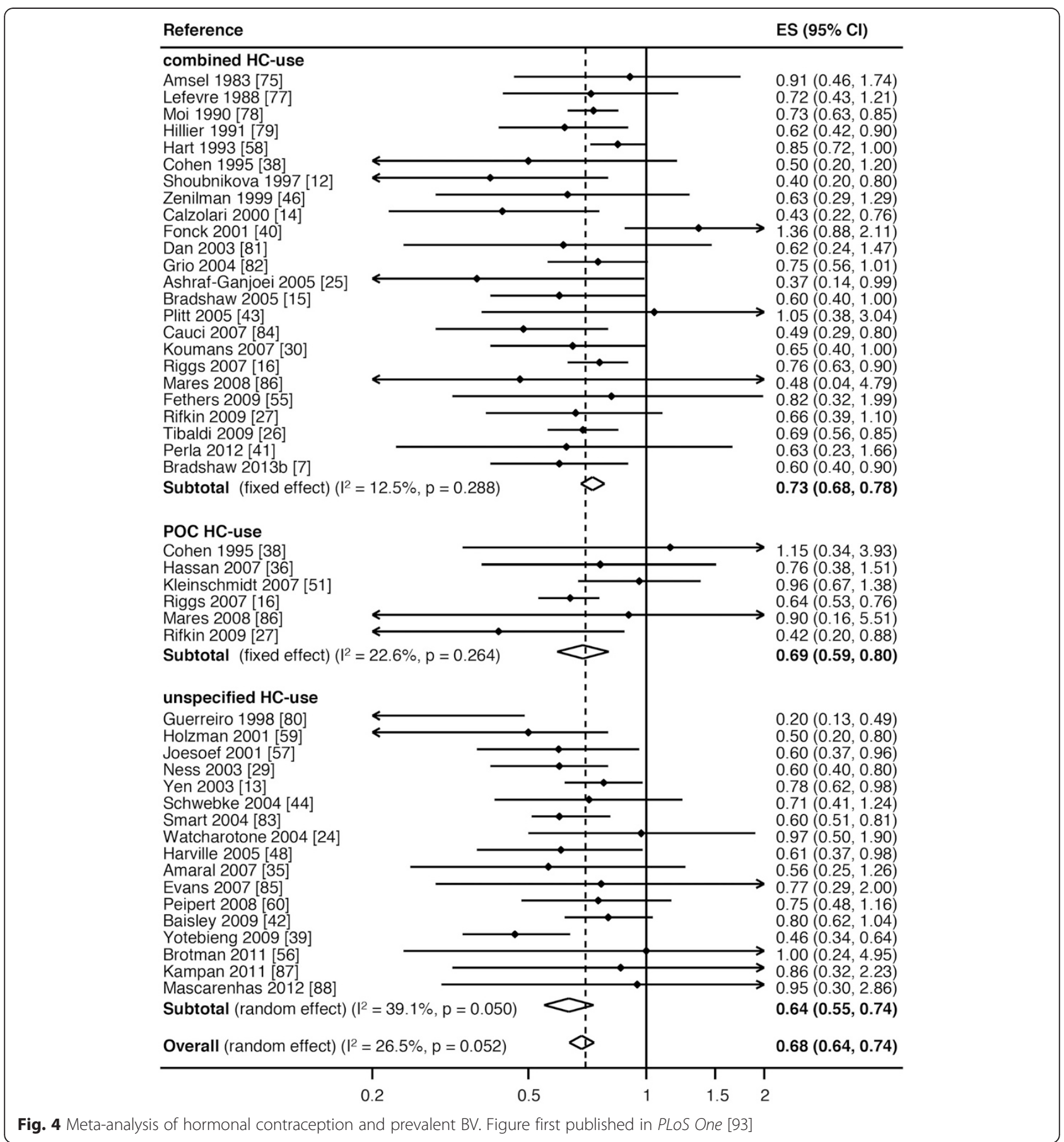




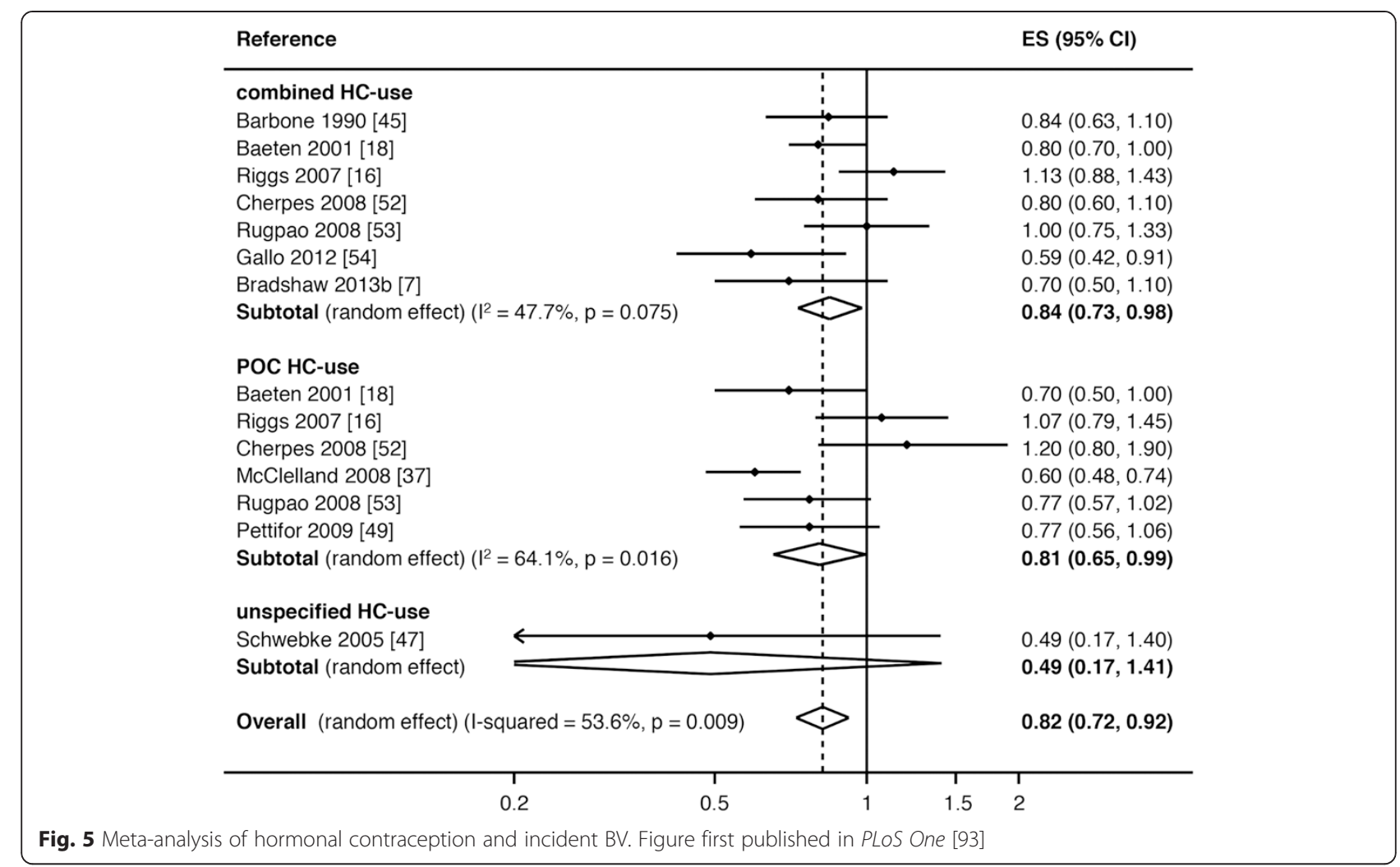

factors including the heterogeneity of approaches used to diagnose $\mathrm{BV}$, the formulation, regimen compliance and duration of $\mathrm{HC}$ use, and the observational nature of the studies. Sexual behaviours, and particularly condom usage, may also confound the relationship between contraceptive method and BV [97].

The effect of $\mathrm{HC}$ on $\mathrm{BV}$ and the vaginal microbiota is likely mediated by sex hormones and their effects on the genital microenvironment and immune response. Adequate estrogen levels increase glycogen production in vaginal epithelial cells, and glycogen is broken down by human alpha-amylase into metabolites used by Lactobacillus spp. to thrive and produce lactic acid [99]. $\mathrm{HC}$, especially those containing progestins, also inhibit uterine bleeding and reduce menstrual loss. Menstruation has been strongly correlated with abnormal vaginal microbiota $[77,79,100]$, perhaps due to blood being a more favourable environment for growth of ironrequiring $\mathrm{BV}$-associated bacteria. $\mathrm{HC}$ may also promote a favourable anti-inflammatory cytokine milieu that facilitates BV clearance, either independently or mediated by the microbiota.

Despite $>50$ years of widespread use, the effect of $\mathrm{HC}$ on mucosal responses and the vaginal microbiota are still incompletely understood. Few studies have fully assessed changes in the vaginal microbiome after initiation or cessation of HC. For a more thorough examination of the complex relationship between $\mathrm{HC}$ and the vaginal microenvironment, we refer the readers to a review by Achilles et al. [101] and meta-analysis by Vodstricil et al. [93]. Future work will clarify whether use of specific HCs are definitively associated with a reduced risk of $\mathrm{BV}$. Investigators are also evaluating lactic acid in the form of a vaginal gel and vaginal ring to determine if it prevents $\mathrm{BV}$, which may be a future therapeutic option alone or in combination with $\mathrm{HCs}$.

\section{New strategies to disrupt BV-associated vaginal biofilm}

As increasing evidence has emerged that BV may be a biofilm-associated disease, an interest has emerged in agents that are primarily aimed at disrupting BVassociated biofilm [102]. It may be necessary to breakdown biofilm to achieve optimal efficacy of antimicrobial or probiotic therapies. Potential candidates that have been investigated include: vaginal boric acid, DNases, retrocyclins, octenidine and some naturally occurring antimicrobials (subtilosin, ploy-L-lysine, lauramide arginine ethyl ester) [103]. Boric acid and octenidine are the only compounds that have been used in human studies, while the remainder have been evaluated in in vitro studies against a G.vaginalis-biofilm [104, 105].

Boric acid $\left(\mathrm{H}_{3} \mathrm{BO}_{3}\right)$, a white, odorless powder, was first used by Lister as a topical antiseptic in 1873 [106], and has been used in the treatment of vulvovaginal candidiasis [107-112] and Trichomonas vaginalis [113]. Vaginal boric acid has bacteriostatic and fungistatic action, yet 
its mechanism of action is unknown [114]. Boric acid may work on BV through decimation of the vaginal biofilm or change in the acidity of the vagina, while the fungistatic activity may be attributed to fungal cell wall penetration or disruption of the fungal cell membrane [115]. Intravaginal boric acid has a long history of clinical use in the treatment of vaginitis and is regarded as a safe secondary regimen [104, 111]. Blood boron analyses indicates little absorption from the vagina [116], and boric acid does not appear to cause adverse changes on cervical cytology [109]. Vulvovaginal burning, watery discharge, erythema, as well as male dyspareunia, are the most frequently reported adverse events reported by a minority of women $[109,115,117]$. Reichman et al. reported on a study of 7 days of oral nitroimidazole administered to 58 women with recurrent BV. Imidazole therapy was followed by 21 days of intravaginal boric acid (600 mg/day) and 16 weeks of suppressive metronidazole gel maintenance therapy if in remission at 21 days [104]. Patients reported symptom improvement and a high cure rate $(87 \%)$ at $2-3$ months on treatment, however, by 38 weeks off treatment the BV recurrence rate was $50 \%$. Current ongoing research is examining how boric acid-based treatments, enhanced with an EDTA excipient to boost antimicrobial activity, may be active against the vaginal biofilm and be a potential candidate for BV treatment [118].

Swidsinski recently reported on the use of the topical antiseptic, octenidine dihydrochloride, for BV-associated biofilm [119]. Octenidine has broad spectrum antimicrobial activity and has been found to be highly effective against biofilms in oral, wound and orthopaedic implant infections [120-123]. Twenty-four patients with recurrent BV were treated with a 7 day intravaginal course of octenidine dihydrochloride spray, and if they failed treatment or recurred within 6 months, they were retreated with a 28 day regimen followed by weekly applications for 2 months [119]. Biofilm was evaluated by fluorescence in situ hybridization on voided vaginal epithelial cells. While early cure rates looked promising after 7 days of topical octenidine $(87.5 \%)$, six month recurrence rates were high $(66.6 \%)$. Repeated treatment for 28 days led to an overall cure rate of $75 \%$, however, complete bacterial resistance to octenidine occurred in a subset of women. Overall, while initial cure rates looked promising, the efficacy of prolonged and repeated treatment was poor and bacterial resistance emerged in a significant proportion of women.

Another novel strategy involves the use of DNAse which targets extracellular DNA (eDNA) [105]. G. vaginalis biofilms contain eDNA which is integral to their structural integrity. Enzymatic disruption of eDNA specifically inhibits biofilm formation and established biofilms. In vitro studies show that low concentrations of DNase and metronidazole have improved efficacy against G. vaginalis biofilm compared with either agent alone, presumably because DNase frees G. vaginalis from the biofilm and renders bacteria more susceptible to the antibiotic. Other in vitro studies have included evaluation of an anti-HIV microbicide candidate RC-101, a synthetic retrocyclin, which is an antimicrobial peptide with antiviral activity. RC-101 has been shown to potently inhibit the activity of vaginolysin, a protein toxin produced by G. vaginalis, and the formation of G. vaginalis biofilms in vitro, without affecting Lactobacillus spp. [124, 125]. Vaginolysin inhibition has been proposed as a potential strategy for BV treatment and prevention [124, 125]. While RC 101 inhibited the formation of GV biofilms, it is not clear if the mechanism is predominantly mediated through vaginolysin inhibition, or another substance involved in biofilm assembly [124, 125]. RC101 may be a candidate for human BV studies. Lastly, a novel area of research involves investigation of agents that inhibit quorum sensing. Quorum sensing is used by some bacterial species such as Pseudomonas aeruginosa and Staphylococcus epidermidis to co-ordinate expression of genes involved in virulence, biofilm formation and pathogenicity [126]. Quorum sensing inhibitors have not yet been evaluated in human studies or BV, but have been shown to be active in vitro against biofilms produced by Pseudomonas aeruginosa and Staphylococcus spp. [126, 127]. Clearly the identification of novel therapeutics that could be used safely in human trials alone or as adjunctive therapies to antibiotics for biofilm-inhibition and disruption is an emerging area of research. For a thorough review of the potential contribution of biofilm to treatment failure and recurrence in BV, we refer readers to an excellent recent publication by Muzny and Schwebke [102].

\section{Conclusion}

No major therapeutic advances have been made in over 20 years that have achieved significant improvements in BV cure rates. We have only begun to understand the importance of the vaginal microbiome and how changes in its composition and function can affect women's health. Approaches that aim to restore a woman's "healthy" vaginal microbiome and maintain homeostasis are much needed to prevent recurrent BV and its sequelae, including transmission and acquisition of HIV and adverse obstetric outcomes, such as preterm birth. While it is fundamentally unknown if BV recurrence is principally due to persistence of BVAB and biofilm, a failure to re-establish a favourable Lactobacillus-dominant vaginal microbiota, reinfection or a combination of these factors, it is challenging to make progress. While evaluating many current and proposed therapies it is important to consider the possibility that reinfection from partners may also be impacting on our ability to 
determine the efficacy of these agents. Clinicians and researchers in the field consider it an urgent priority to develop new and innovative approaches to the management of BV in order to achieve high and sustained longterm cure rates, to develop effective prevention strategies and to reduce $\mathrm{BV}$-associated sequelae. In order to achieve sustained cure it is possible, even likely, that we may need an approach that combines a number of these strategies such as use of antibiotics with biofilm-disrupting agents and partner treatment.

\section{Competing interests}

The authors declare that they have no competing interests.

\section{Authors' contributions}

CSB and RMB both contributed to the conceptualization, drafting and revision of this manuscript. Both authors read and approved the final manuscript.

\section{Acknowledgements}

RMB has received funding from the U.S. National Institute of Allergy and Infectious Diseases K01-Al080974. CSB did not receive funding for preparation of this manuscript.

\section{Author details}

${ }^{1}$ Melbourne Sexual Health Centre, 580 Swanston Street, Carlton, VIC 3053, Australia. ${ }^{2}$ Central Clinical School, Monash University, Melbourne, VIC, Australia. ${ }^{3}$ Institute for Genome Sciences, University of Maryland School of Medicine, Baltimore, MD, USA.

Received: 12 May 2015 Accepted: 15 July 2015

Published online: 29 July 2015

\section{References}

1. Bradshaw CS, Walker J, Fairley CK, Chen MY, Tabrizi SN, Donovan B, et al. Prevalent and incident bacterial vaginosis are associated with sexual and contraceptive behaviours in young Australian women. PLoS One. 2013;8(3):e57688.

2. Koumans EH, Sternberg M, Bruce C, McQuillan G, Kendrick J, Sutton M, et al. The prevalence of bacterial vaginosis in the United States, 2001-2004; associations with symptoms, sexual behaviors, and reproductive health. Sex Transm Dis. 2007;34(11):864-9.

3. Allsworth JE. Bacterial vaginosis-race and sexual transmission: issues of causation. Sex Transm Dis. 2010;37(3):137-9.

4. Chico RM, Mayaud P, Ariti C, Mabey D, Ronsmans C, Chandramohan D. Prevalence of malaria and sexually transmitted and reproductive tract infections in pregnancy in sub-Saharan Africa: a systematic review. JAMA. 2012;307(19):2079-86.

5. Koumans EH, Markowitz LE, Hogan V. Indications for therapy and treatment recommendations for bacterial vaginosis in nonpregnant and pregnant women: a synthesis of data. Clin Infect Dis. 2002;35 Suppl 2:S152-72.

6. Brotman RM, Klebanoff MA, Nansel TR, Yu KF, Andrews WW, Zhang J, et al. Bacterial vaginosis assessed by gram stain and diminished colonization resistance to incident gonococcal, chlamydial, and trichomonal genital infection. J Infect Dis. 2010;202(12):1907-15.

7. Peipert JF, Lapane KL, Allsworth JE, Redding CA, Blume JD, Stein MD. Bacterial vaginosis, race, and sexually transmitted infections: does race modify the association? Sex Transm Dis. 2008;35(4):363-7.

8. Martin H, Richardson B, Nyange P, Lavreys L, Hillier S, Chohan B, et al. Vaginal lactobacilli, microbial flora, and risk of human immunodeficiency virus type 1 and sexually transmitted disease acquisition. J Infect Dis. 1999;180:1863-8.

9. Myer L, Kuhn L, Stein ZA, Wright Jr TC, Denny L. Intravaginal practices, bacterial vaginosis, and women's susceptibility to HIV infection: epidemiological evidence and biological mechanisms. Lancet Infect Dis. 2005;5(12):786-94
10. Cherpes T, Meyn L, Krohn M, Lurie J, Hillier S. Association between acquisition of herpes simplex virus type 2 in women and bacterial vaginosis. Clin Infect Dis. 2003;37:319-25.

11. Martin DH. The microbiota of the vagina and its influence on women's health and disease. Am J Med Sci. 2012;343:2-9.

12. Cohen CR, Lingappa JR, Baeten JM, Ngayo MO, Spiegel CA, Hong T, et al. Bacterial vaginosis associated with increased risk of female-to-male HIV-1 transmission: a prospective cohort analysis among African couples. PLoS Med. 2012;9(6):e1001251.

13. Bilardi JE, Walker S, Temple-Smith M, McNair R, Mooney-Somers J, Bellhouse $C$, et al. The burden of bacterial vaginosis: women's experience of the physical, emotional, sexual and social impact of living with recurrent bacterial vaginosis. PLoS One. 2013;8(9):e74378.

14. Fredricks DN, Marrazzo JM. Molecular methodology in determining vaginal flora in health and disease: its time has come. Curr Infect Dis Rep. 2005;7(6):463-70.

15. Fredricks DN, Fiedler TL, Marrazzo JM. Molecular identification of bacteria associated with bacterial vaginosis. N Engl J Med. 2005;353(18):1899-911.

16. Fredricks DN, Fiedler TL, Thomas KK, Oakley BB, Marrazzo JM. Targeted PCR for detection of vaginal bacteria associated with bacterial vaginosis. J Clin Microbiol. 2007:45(10):3270-6.

17. Boskey ER, Cone RA, Whaley KJ, Moench TR. Origins of vaginal acidity: high $\mathrm{D} / \mathrm{L}$ lactate ratio is consistent with bacteria being the primary source. Hum Reprod. 2001;16(9):1809-13.

18. Aroutcheva A, Gariti D, Simon M, Shott S, Faro J, Simoes JA, et al. Defense factors of vaginal lactobacilli. Am J Obstet Gynecol. 2001;185(2):375-9.

19. Donia MS, Cimermancic P, Schulze CJ, Wieland Brown LC, Martin J, Mitreva $M$, et al. A systematic analysis of biosynthetic gene clusters in the human microbiome reveals a common family of antibiotics. Cell. 2014;158(6):1402-14.

20. Aldunate M, Tyssen D, Johnson A, Zakir T, Sonza S, Moench T, et al. Vaginal concentrations of lactic acid potently inactivate HIV. J Antimicrob Chemother. 2013;68(9):2015-25.

21. O'Hanlon DE, Moench TR, Cone RA. In vaginal fluid, bacteria associated with bacterial vaginosis can be suppressed with lactic acid but not hydrogen peroxide. BMC Infect Dis. 2011;11(1):200.

22. Witkin SS, Alvi S, Bongiovanni AM, Linhares IM, Ledger WJ. Lactic acid stimulates interleukin-23 production by peripheral blood mononuclear cells exposed to bacterial lipopolysaccharide. FEMS Immunol Med Microbiol. 2011;61(2):153-8.

23. Phukan N, Parsamand T, Brooks AE, Nguyen TN, Simoes-Barbosa A. The adherence of Trichomonas vaginalis to host ectocervical cells is influenced by lactobacilli. Sex Transm Infect. 2013;89(6):455-9.

24. Macklaim JM, Gloor GB, Anukam KC, Cribby S, Reid G. At the crossroads of vaginal health and disease, the genome sequence of Lactobacillus iners AB-1. Proc Natl Acad Sci U S A. 2011;108 Suppl 1:4688-95.

25. McMillan A, Macklaim JM, Burton JP, Reid G. Adhesion of lactobacillus iners AB-1 to human fibronectin: a key mediator for persistence in the vagina? Reprod Sci. 2013;20(7):791-6.

26. Verstraelen $H$, Verhelst $R$, Claeys $G$, De Backer $E$, Temmerman $M$, Vaneechoutte M. Longitudinal analysis of the vaginal microflora in pregnancy suggests that $L$. crispatus promotes the stability of the normal vaginal microflora and that $L$. gasseri and/or L. iners are more conducive to the occurrence of abnormal vaginal microflora. BMC Microbiol. 2009;9:116.

27. Witkin SS, Mendes-Soares H, Linhares IM, Jayaram A, Ledger WJ, Forney LJ. Influence of vaginal bacteria and D- and L-lactic acid isomers on vaginal extracellular matrix metalloproteinase inducer: implications for protection against upper genital tract infections. MBio. 2013;4(4):e00460-13.

28. Fredricks DN. Molecular methods to describe the spectrum and dynamics of the vaginal microbiota. Anaerobe. 2011;17(4):191-5.

29. Zozaya-Hinchliffe M, Lillis R, Martin DH, Ferris MJ. Quantitative PCR assessments of bacterial species in women with and without bacterial vaginosis. J Clin Microbiol. 2010;48(5):1812-9.

30. Swidsinski A, Mendling W, Loening-Baucke V, Ladhoff A, Swidsinski S, Hale $L P$, et al. Adherent biofilms in bacterial vaginosis. Obstet Gynecol. 2005;106(5 Pt 1):1013-23.

31. Swidsinski A, Mendling W, Loening-Baucke $V$, Swidsinski S, Dorffel Y, Scholze J, et al. An adherent Gardnerella vaginalis biofilm persists on the vaginal epithelium after standard therapy with oral metronidazole. Am J Obstet Gynecol. 2008;198(1):97.e1-6. 
32. Averette HE, Weinstein GD, Frost P. Autoradiographic analysis of cell proliferation kinetics in human genital tissues. I. Normal cervix and vagina. Am J Obstet Gynecol. 1970;108(1):8-17.

33. Yildirim S, Yeoman CJ, Janga SC, Thomas SM, Ho M, Leigh SR, et al. Primate vaginal microbiomes exhibit species specificity without universal Lactobacillus dominance. ISME J. 2014:8(12):2431-44.

34. Neuendorf E, Gajer P, Bowlin AK, Marques PX, Ma B, Yang H, et al. Chlamydia caviae infection alters abundance but not composition of the guinea pig vaginal microbiota. Pathog Dis. 2015;73(4):ftv019.

35. Noguchi K, Tsukumi K, Urano T. Qualitative and quantitative differences in normal vaginal flora of conventionally reared mice, rats, hamsters, rabbits, and dogs. Comp Med. 2003;53(4):404-12.

36. Rivera AJ, Frank JA, Stumpf R, Salyers AA, Wilson BA, Olsen GJ, et al. Differences between the normal vaginal bacterial community of baboons and that of humans. Am J Primatol. 2011;73(2):119-26.

37. Stumpf RM, Wilson BA, Rivera A, Yildirim S, Yeoman CJ, Polk JD, et al. The primate vaginal microbiome: comparative context and implications for human health and disease. Am J Phys Anthropol. 2013;152 Suppl 57:119-34.

38. Oduyebo OO, Anorlu Rl, Ogunsola FT. The effects of antimicrobial therapy on bacterial vaginosis in non-pregnant women. Cochrane Database Syst Rev. 2009;3:CD006055.

39. Sobel JD, Schmitt C, Meriwether C. Long-term follow-up of patients with bacterial vaginosis treated with oral metronidazole and topical clindamycin. J Infect Dis. 1993;167(3):783-4.

40. Bradshaw CS, Morton AN, Hocking J, Garland SM, Morris MB, Moss LM, et al. High recurrence rates of bacterial vaginosis over the course of 12 months after oral metronidazole therapy and factors associated with recurrence. J Infect Dis. 2006;193(11):1478-86.

41. Marrazzo JM, Thomas KK, Fiedler TL, Ringwood K, Fredricks DN. Relationship of specific vaginal bacteria and bacterial vaginosis treatment failure in women who have sex with women. Ann Intern Med. 2008;149(1):20-8.

42. Sobel JD, Ferris D, Schwebke J, Nyirjesy P, Wiesenfeld HC, Peipert J, et al. Suppressive antibacterial therapy with $0.75 \%$ metronidazole vaginal gel to prevent recurrent bacterial vaginosis. Am J Obstet Gynecol. 2006;194(5):1283-9.

43. Taha TE, Kumwenda NI, Kafulafula G, Makanani B, Nkhoma C, Chen S, et al. Intermittent intravaginal antibiotic treatment of bacterial vaginosis in HIV-uninfected and -infected women: a randomized clinical trial. PLoS Clin Trials. 2007;2(2):e10.

44. Hawes SE, Hillier SL, Benedetti J, Stevens CE, Koutsky LA, Wolner-Hanssen P, et al. Hydrogen peroxide-producing lactobacilli and acquisition of vaginal infections. J Infect Dis. 1996;174(5):1058-63.

45. Fethers KA, Fairley CK, Hocking JS, Gurrin LC, Bradshaw CS. Sexual risk factors and bacterial vaginosis: a systematic review and meta-analysis. Clin Infect Dis. 2008:47(11):1426-35.

46. Fethers KA, Fairley CK, Morton A, Hocking JS, Hopkins C, Kennedy LJ, et al. Early sexual experiences and risk factors for bacterial vaginosis. J Infect Dis. 2009;200(11):1662-70.

47. Bump RC, Buesching III WJ. Bacterial vaginosis in virginal and sexually active adolescent females: evidence against exclusive sexual transmission. Am J Obstet Gynecol. 1988;158(4):935-9.

48. Yen S, Shafer MA, Moncada J, Campbell CJ, Flinn SD, Boyer CB. Bacterial vaginosis in sexually experienced and non-sexually experienced young women entering the military. Obstet Gynecol. 2003;102(5 Pt 1):927-33.

49. Potter J. Should sexual partners of women with bacterial vaginosis receive treatment? Br J Gen Pract. 1999:49(448):913-8.

50. Mehta SD. Systematic review of randomized trials of treatment of male sexual partners for improved bacterial vaginosis outcomes in women. Sex Transm Dis. 2012;39(10):822-30

51. Bradshaw CS, Vodstrcil LA, Hocking JS, Law M, Pirotta M, Garland SM, et al. Recurrence of bacterial vaginosis is significantly associated with post treatment sexual activities and hormonal contraceptive use. Clin Infect Dis. 2013;56(6):777-86

52. Sanchez S, Garcia PJ, Thomas KK, Catlin M, Holmes KK. Intravaginal metronidazole gel versus metronidazole plus nystatin ovules for bacterial vaginosis: a randomized controlled trial. Am J Obstet Gynecol. 2004;191(6):1898-906.

53. Schwebke JR, Desmond RA. A randomized trial of the duration of therapy with metronidazole plus or minus azithromycin for treatment of symptomatic bacterial vaginosis. Clin Infect Dis. 2007;44(2):213-9.
54. Schwebke JR, Muzny CA, Josey WE. Role of Gardnerella vaginalis in the pathogenesis of bacterial vaginosis: a conceptual model. J Infect Dis. 2014;210(3):338-43.

55. Bradshaw CS, Tabrizi SN, Read TRH, Garland SM, Hopkins CA, Moss LM, et al. Etiologies of non-gonococcal urethritis: bacteria, viruses and the association with oro-genital exposure. J Infect Dis. 2006;193:336-45.

56. Piot P. Distribution of eight serotypes of Ureaplasma urealyticum in cases of non-gonococcal urethritis and of gonorrhoea, and in healthy persons. Br J Vener Dis. 1976;52(4):266-8.

57. Schwebke JR, Rivers C, Lee J. Prevalence of Gardnerella vaginalis in male sexual partners of women with and without bacterial vaginosis. Sex Transm Dis. 2009;36(2):92-4.

58. Nelson DE, Dong Q, Van der Pol B, Toh E, Fan B, Katz BP, et al. Bacterial communities of the coronal sulcus and distal urethra of adolescent males. PLoS One. 2012;7(5):e36298.

59. Price LB, Liu CM, Johnson KE, Aziz M, Lau MK, Bowers J, et al. The effects of circumcision on the penis microbiome. PLoS One. 2010;5(1):e8422.

60. Gray RH, Wawer MJ, Serwadda D, Kigozi G. The role of male circumcision in the prevention of human papillomavirus and HIV infection. J Infect Dis. 2009;199(1):1-3.

61. Swidsinski A, Loening-Baucke V, Mendling W, Dorffel Y, Schilling J, Halwani $Z$, et al. Infection through structured polymicrobial Gardnerella biofilms (StPM-GB). Histol Histopathol. 2014;29(5):567-87.

62. Berger BJ, Kolton S, Zenilman JM, Cummings MC, Feldman J, McCormack WM. Bacterial vaginosis in lesbians: a sexually transmitted disease. Clin Infect Dis. 1995;21(6):1402-5.

63. Marrazzo JM, Koutsky LA, Eschenbach DA, Agnew K, Stine K, Hillier SL. Characterization of vaginal flora and bacterial vaginosis in women who have sex with women. J Infect Dis. 2002;185(9):1307-13.

64. Bailey JV, Farquhar C, Owen C. Bacterial vaginosis in lesbians and bisexual women. Sex Transm Dis. 2004;31(11):691-4.

65. Evans AL, Scally AJ, Wellard SJ, Wilson JD. Prevalence of bacterial vaginosis in lesbians and heterosexual women in a community setting. Sex Transm Infect. 2007;83(6):470-5.

66. Bradshaw CS, Walker SM, Vodstrcil LA, Bilardi JE, Law M, Hocking JS, et al. The influence of behaviors and relationships on the vaginal microbiota of women and their female partners: the WOW Health Study. J Infect Dis. 2014;209(10):1562-72.

67. Marrazzo JM, Thomas KK, Fiedler TL, Ringwood K, Fredricks DN. Risks for acquisition of bacterial vaginosis among women who report sex with women: a cohort study. PLoS One. 2010;5(6):e11139.

68. Vodstrcil LA, Walker SM, Hocking JS, Law M, Forcey DS, Fehler G, et al. Incident bacterial vaginosis (BV) in women who have sex with women is associated with behaviors that suggest sexual transmission of BV. Clin Infect Dis. 2015:60(7):1042-53.

69. Marrazzo JM, Antonio M, Agnew K, Hillier SL. Distribution of genital Lactobacillus strains shared by female sex partners. J Infect Dis. 2009;199(5):680-3.

70. Ravel J, Gajer P, Abdo Z, Schneider GM, Koenig SS, McCulle SL, et al. Vaginal microbiome of reproductive-age women. Proc Natl Acad Sci U S A. 2011;108 Suppl 1:4680-7.

71. Zhou X, Hansmann MA, Davis CC, Suzuki H, Brown CJ, Schütte U, et al. The vaginal bacterial communities of Japanese women resemble those of women in other racial groups. FEMS Immunol Med Microbiol. 2010:58(2):169-81.

72. Zhou X, Brown CJ, Abdo Z, Davis CC, Hansmann MA, Joyce P, et al. Differences in the composition of vaginal microbial communities found in healthy Caucasian and black women. ISME J. 2007;1(2):121-33.

73. Fredricks DN, Fiedler TL, Thomas KK, Mitchell CM, Marrazzo JM. Changes in vaginal bacterial concentrations with intravaginal metronidazole therapy for bacterial vaginosis as assessed by quantitative PCR. J Clin Microbiol. 2009:47(3):721-6.

74. Martin DH, Zozaya M, Lillis RA, Myers L, Nsuami MJ, Ferris MJ. Unique vaginal microbiota that includes an unknown Mycoplasma-like organism is associated with Trichomonas vaginalis infection. J Infect Dis. 2013;207(12):1922-31.

75. Benning L, Golub ET, Anastos K, French AL, Cohen M, Gilbert D, et al. Comparison of lower genital tract microbiota in HIV-infected and uninfected women from Rwanda and the US. PLoS One. 2014;9(5):e96844. 
76. Chaban B, Links MG, Jayaprakash TP, Wagner EC, Bourque DK, Lohn Z, et al. Characterization of the vaginal microbiota of healthy Canadian women through the menstrual cycle. Microbiome. 2014;2:23.

77. Gajer P, Brotman RM, Bai G, Sakamoto J, Schutte UM, Zhong X, et al. Temporal dynamics of the human vaginal microbiota. Sci Transl Med. 2012;4(132):132ra152.

78. Ravel J, Brotman RM, Gajer P, Ma B, Nandy M, Fadrosh DW, et al. Daily temporal dynamics of vaginal microbiota before, during and after episodes of bacterial vaginosis. Microbiome. 2013;1(1):29.

79. Srinivasan S, Liu C, Mitchell CM, Fiedler TL, Thomas KK, Agnew KJ, et al. Temporal variability of human vaginal bacteria and relationship with bacterial vaginosis. PLoS One. 2010;5(4):e10197.

80. Senok AC, Verstraelen H, Temmerman M, Botta GA. Probiotics for the treatment of bacterial vaginosis. Cochrane Database Syst Rev. 2009:4:CD006289.

81. Mastromarino P, Macchia S, Meggiorini L, Trinchieri V, Mosca L, Perluigi M, et al. Effectiveness of Lactobacillus-containing vaginal tablets in the treatment of symptomatic bacterial vaginosis. Clin Microbiol Infect. 2009;15(1):67-74

82. Hemmerling A, Harrison W, Schroeder A, Park J, Korn A, Shiboski S, et al. Phase 2a study assessing colonization efficiency, safety, and acceptability of Lactobacillus crispatus CTV-05 in women with bacterial vaginosis. Sex Transm Dis. 2010;37(12):745-50.

83. Antonio MA, Meyn LA, Murray PJ, Busse B, Hillier SL. Vaginal colonization by probiotic Lactobacillus crispatus CTV-05 is decreased by sexual activity and endogenous Lactobacilli. J Infect Dis. 2009;199(10):1506-13.

84. Ngugi BM, Hemmerling A, Bukusi EA, Kikuvi G, Gikunju J, Shiboski S, et al. Effects of bacterial vaginosis-associated bacteria and sexual intercourse on vaginal colonization with the probiotic lactobacillus crispatus CTV-05. Sex Transm Dis. 2011;38(11):1020-7.

85. Hemalatha R, Mastromarino P, Ramalaxmi BA, Balakrishna NV, Sesikeran B. Effectiveness of vaginal tablets containing lactobacilli versus $\mathrm{pH}$ tablets on vaginal health and inflammatory cytokines: a randomized, double-blind study. Eur J Clin Microbiol Infect Dis. 2012;31(11):3097-105.

86. Reid G, Charbonneau D, Erb J, Kochanowski B, Beuerman D, Poehner R, et al. Oral use of Lactobacillus rhamnosus GR-1 and L. fermentum RC-14 significantly alters vaginal flora: randomized, placebo-controlled trial in 64 healthy women. FEMS Immunol Med Microbiol. 2003;35(2):131-4.

87. Martinez R, Franceschini S, Patta M. Improved cure of bacterial vaginosis with single dose of tinidazole (2 g), Lactobacillus rhamnosus GR-1, and Lactobacillus reuteri RC-14: a randomized, double-blind, placebo-controlled trial. Can J Microbiol. 2009;55(2):133-8.

88. Workowski KA, Berman S, Centers for Disease Control and Prevention. Sexually transmitted diseases treatment guidelines, 2010. MMWR Recomm Rep. 2010;59(RR-12):1-110.

89. Riggs M, Klebanoff M, Nansel T, Zhang J, Schwebke J, Andrews W. Longitudinal association between hormonal contraceptives and bacterial vaginosis in women of reproductive age. Sex Transm Dis. 2007;34(12):954-9.

90. Shoubnikova M, Hellberg D, Nilsson S, Mardh PA. Contraceptive use in women with bacterial vaginosis. Contraception. 1997;55(6):355-8.

91. Rifkin SB, Smith MR, Brotman RM, Gindi RM, Erbelding EJ. Hormonal contraception and risk of bacterial vaginosis diagnosis in an observational study of women attending STD clinics in Baltimore, MD. Contraception. 2009;80(1):63-7.

92. Baeten JM, Nyange PM, Richardson BA, Lavreys L, Chohan B, Martin Jr HL, et al. Hormonal contraception and risk of sexually transmitted disease acquisition: results from a prospective study. Am J Obstet Gynecol. 2001;185(2):380-5.

93. Vodstrcil LA, Hocking JS, Law M, Walker S, Tabrizi SN, Fairley CK, et al. Hormonal contraception is associated with a reduced risk of bacterial vaginosis: a systematic review and meta-analysis. PLoS One. 2013;8(9):e73055

94. De Seta F, Restaino S, De Santo D, Stabile G, Banco R, Busetti M, et al. Effects of hormonal contraception on vaginal flora. Contraception. 2012;86(5):526-9

95. Veres $\mathrm{S}$, Miller $\mathrm{L}$, Burington $\mathrm{B}$. A comparison between the vaginal ring and oral contraceptives. Obstet Gynecol. 2004;104(3):555-63.

96. Calzolari E, Masciangelo R, Milite V, Verteramo R. Bacterial vaginosis and contraceptive methods. Int J Gynaecol Obstet. 2000;70(3):341-6.

97. Madden T, Grentzer JM, Secura GM, Allsworth JE, Peipert JF. Risk of bacterial vaginosis in users of the intrauterine device. Sex Transm Dis. 2012;39(3):217-22.
98. Jacobson JC, Turok DK, Dermish Al, Nygaard IE, Settles ML. Vaginal microbiome changes with levonorgestrel intrauterine system placement. Contraception. 2014;90(2):130-5.

99. Spear GT, French AL, Gilbert D, Zariffard MR, Mirmonsef P, Sullivan TH, et al. Human alpha-amylase present in lower-genital-tract mucosal fluid processes glycogen to support vaginal colonization by Lactobacillus. J Infect Dis. 2014;210(7):1019-28.

100. Eschenbach DA, Thwin SS, Patton DL, Hooton TM, Stapleton AE, Agnew K, et al. Influence of the normal menstrual cycle on vaginal tissue, discharge, and microflora. Clin Infect Dis. 2000;30(6):901-7.

101. Achilles SL, Hillier SL. The complexity of contraceptives: understanding their impact on genital immune cells and vaginal microbiota. AIDS. 2013;27 Suppl 1:S5-15.

102. Muzny CA, Schwebke JR. Biofilms: an underappreciated mechanism of treatment failure and recurrence in vaginal infections. Clin Infect Dis. 2015. [Epub ahead of print].

103. Turovskiy $Y$, Cheryian T, Algburi A, Wirawan RE, Takhistov P, Sinko PJ, et al. Susceptibility of Gardnerella vaginalis biofilms to natural antimicrobials subtilosin, epsilon-poly-L-lysine, and lauramide arginine ethyl ester. Infect Dis Obstet Gynecol. 2012;2012:284762.

104. Reichman O, Akins R, Sobel JD. Boric acid addition to suppressive antimicrobial therapy for recurrent bacterial vaginosis. Sex Transm Dis. 2009;36(11):732-4.

105. Hymes SR, Randis TM, Sun TY, Ratner AJ. DNase inhibits gardnerella vaginalis biofilms in vitro and in vivo. J Infect Dis. 2013;207(10):1491-7.

106. Dukes MNG; Excerpta Medica Foundation. Side effects of drugs annual. Amsterdam, New York: Excerpta Medica; sole distributors for the USA and Canada: Elsevier/North Holland.

107. Van Kessel K, Assefi N, Marrazzo J, Eckert L. Common complementary and alternative therapies for yeast vaginitis and bacterial vaginosis: a systematic review. Obstet Gynecol Surv. 2003;58(5):351-8.

108. Swate TE, Weed JC. Boric acid treatment of vulvovaginal candidiasis. Obstet Gynecol. 1974;43(6):893-5.

109. Van Slyke KK, Michel VP, Rein MF. Treatment of vulvovaginal candidiasis with boric acid powder. Am J Obstet Gynecol. 1981;141(2):145-8.

110. Singh S, Sobel JD, Bhargava P, Boikov D, Vazquez JA. Vaginitis due to Candida krusei: epidemiology, clinical aspects, and therapy. Clin Infect Dis. 2002;35(9):1066-70.

111. Sobel JD, Chaim W, Nagappan V, Leaman D. Treatment of vaginitis caused by Candida glabrata: use of topical boric acid and flucytosine. Am J Obstet Gynecol. 2003;189(5):1297-300.

112. Workowski KA, Bolan GA. Sexually transmitted diseases treatment guidelines, 2015. MMWR Recomm Rep. 2015;64(RR-03):1-137.

113. Aggarwal A, Shier RM. Recalcitrant Trichomonas vaginalis infections successfully treated with vaginal acidification. J Obstet Gynaecol Can. 2008;30(1):55-8.

114. Prutting SM, Cerveny JD. Boric acid vaginal suppositories: a brief review. Infect Dis Obstet Gynecol. 1998;6(4):191-4.

115. Shinohara YT, Tasker SA. Successful use of boric acid to control azolerefractory Candida vaginitis in a woman with AIDS. J Acquir Immune Defic Syndr Hum Retrovirol. 1997:16(3):219-20.

116. Van Slyke KK, Michel VP, Rein MF. The boric acid powder treatment of vulvovaginal candidiasis. J Am Coll Health Assoc. 1981;30(3):107-9.

117. Sobel JD, Chaim W. Treatment of Torulopsis glabrata vaginitis: retrospective review of boric acid therapy. Clin Infect Dis. 1997;24(4):649-52.

118. Pulcini E. Effects of boric acid (BA) and TOL-463 against biofilms formed by key vaginitis pathogens gardnerella vaginalis and candida albicans. Infect Dis Soc Obstet Gynecol Stowe Vermont. 2014.

119. Swidsinski A, Loening-Baucke V, Swidsinski S, Verstraelen H. Polymicrobia Gardnerella biofilm resists repeated intravaginal antiseptic treatment in a subset of women with bacterial vaginosis: a preliminary report. Arch Gynecol Obstet. 2015;291(3):605-9.

120. Rupf S, Balkenhol M, Sahrhage TO, Baum A, Chromik JN, Ruppert K, et al. Biofilm inhibition by an experimental dental resin composite containing octenidine dihydrochloride. Dent Mater. 2012;28(9):974-84.

121. Hubner NO, Siebert J, Kramer A. Octenidine dihydrochloride, a modern antiseptic for skin, mucous membranes and wounds. Skin Pharmacol Physiol. 2010;23(5):244-58.

122. Sennhenn-Kirchner S, Wolff N, Klaue S, Mergeryan H, Borg-von Zepelin M. Decontamination efficacy of antiseptic agents on in vivo grown biofilms on rough titanium surfaces. Quintessence Int. 2009;40(10):e80-8. 
123. Bartoszewicz M, Rygiel A, Krzeminski M, Przondo-Mordarska A. Penetration of a selected antibiotic and antiseptic into a biofilm formed on orthopedic steel implants. Ortop Traumatol Rehabil. 2007;9(3):310-8.

124. Eade CR, Cole AL, Diaz C, Rohan LC, Parniak MA, Marx P, et al. The anti-HIV microbicide candidate RC-101 inhibits pathogenic vaginal bacteria without harming endogenous flora or mucosa. Am J Reprod Immunol. 2013;69(2):150-8

125. Hooven TA, Randis TM, Hymes SR, Rampersaud R, Ratner AJ. Retrocyclin inhibits Gardnerella vaginalis biofilm formation and toxin activity. J Antimicrob Chemother. 2012;67(12):2870-2.

126. Brackman G, Coenye T. Quorum sensing inhibitors as anti-biofilm agents. Curr Pharm Des. 2015;21(1):5-11.

127. Deng Y, Lim A, Lee J, Chen S, An S, Dong YH, et al. Diffusible signal factor (DSF) quorum sensing signal and structurally related molecules enhance the antimicrobial efficacy of antibiotics against some bacterial pathogens. BMC Microbiol. 2014;14:51

\section{Submit your next manuscript to BioMed Central and take full advantage of:}

- Convenient online submission

- Thorough peer review

- No space constraints or color figure charges

- Immediate publication on acceptance

- Inclusion in PubMed, CAS, Scopus and Google Scholar

- Research which is freely available for redistribution 